ний живых лиц, а также структуру привлечений врачей к проведению комиссионных судебно-медицинских экспертиз. Установлено высокое значение удельного веса участия врачей в проведении судебно-медицинских экспертиз Закарпатского областного бюро судебно-медицинской экспертизы на протяжении последних 3 лет.

Ключевые слова: эксперт, специалист-эксперт, комиссионная судебно-медицинская экспертиза.

\title{
AN ANALYSIS OF DOCTORS' PARTICIPATION IN PERFORMING FORENSIC MEDICAL EXAMINATIONS OF THE TRANSCARPATHIAN REGIONAL BUREAU OF FORENSIC MEDICAL EXAMINATIONS DURING A PERIOD FROM 2010 THROUGH 2012

\author{
${ }^{1}$ V.L. Fentsyk, ${ }^{1}$ V.M. Shymon, ${ }^{2}$ Ya.V. Tovtyn, ${ }^{3}$ Yu.R. Fentsyk
}

Abstract. This paper provides an analysis of the number of cases, involving doctors to conduct forensic examinations of the Transcarpathian Regional Bureau of Forensic Medicine in 2010-2012. A distribution of the number of consultations provided by physicians during forensic examinations of living persons, as well as the structure of enlisting doctors for commission forensic medical examinations has been analyzed. A high value of the share of examinations with the doctors in performing forensic examinations in the Transcarpathian Regional Bureau of Forensic Medicine over the last 3 years has been established.

Key words: expert, expert consultant, commission forensic-medical examination.

$$
\begin{array}{r}
{ }^{1} \text { National University (Uzhgorod) } \\
{ }^{2} \text { Transcarpathian Regional Bureau of Forensic Medical Examination (Uzhgorod) } \\
{ }^{3} \text { Transcarpathian Territorial Center of Emergency Medical Care (Uzhgorod) }
\end{array}
$$

\section{В.В. Франчук, Я.Я. Боднар, С.В. Трач-Росоловська, А.З. Миколенко УПРОВАДЖЕННЯ ІННОВАЦІЙНИХ ТЕХНОЛОГІЙ НАВЧАННЯ У ВИКЛАДАННЯ ДИСЦИПЛІНИ «СУДОВА МЕДИЦИНА, МЕДИЧНЕ ЗАКОНОДАВСТВО»}

ДВНЗ «Тернопільський державний медичний університет ім. І.Я. Горбачевського»

\begin{abstract}
Резюме. У статті висвітлено сучасні технології навчання, які впроваджені у викладання судової медицини в Тернопільському державному медичному університеті.
\end{abstract}

Вступ. Втілення вимог Болонської декларації $з$ метою подальшої інтеграції у світовий освітній простір є нагальною потребою реформування вищої медичної освіти [5]. Це зумовлює впровадження кардинальних змін у методологію навчання шляхом пошуку нових і удосконалення існуючих методик викладання та застосування новітніх інформаційно-комунікативних технологій [1]. Серед таких інновацій у вищій медичній школі $є$ навчання за кредитно-модульною системою [3].

Теоретичні знання та відповідні практичні навички 3 дисципліни «Судова медицина, медичне законодавство» мають важливе значення, оскільки необхідні майбутньому лікарю, у т.ч. як спеціалісту або експерту, який може бути залучений судово-слідчими органами до певних процесуальних дій, передбачених новим Кримінальним процесуальним кодексом України, що набув чинності 20 листопада 2012 року. Водночас методо- логічна основа формування професійної компетентності лікаря в галузі судової медицини, судовомедичної експертизи та медичного законодавства має потребу у вдосконаленні та корекції [4].

Мета дослідження. Оприлюднити особливості нових технологій засвоєння студентами практичних навичок і теоретичного матеріалу 3 дисципліни «Судова медицина, медичне законодавство» за кредитно-модульною системою, запроваджених у ДВНЗ “Тернопільський державний медичний університет імені I.Я. Горбачевського МОЗ України".

Результати дослідження та їх обговорення. Кредитно-модульна система організації навчального процесу на кафедрі патологічної анатомії 3 секційним курсом та судовою медициною ТДМУ започаткована з 2007 року - на медичному факультеті і з 2010 - на стоматологічному. 3 цього часу використовуються сучасні, широко апробовані в багатьох європейських університетах, тех- 
нології навчання: методика «єдиного дня», циклова система, дистанційне оцінювання знань студентів, єдиний комплексний тестовий іспит. Всі вони стали можливими внаслідок тісної співпраці ТДМУ з кращими університетами Центральної та Східної Свропи, а також - завдяки масштабній комп'ютеризації всіх кафедр, підрозділів, студентів та викладачів із під'єднанням їх як до загальносвітової інтернетмережі, так і до власного внутрішньоуніверситетського інтернету.

Вивчення судової медицини у ТДМУ здійснюється за методикою “єдиного дня”, протягом восьми окремих навчальних днів. У 2012 році запроваджена циклова система навчання, яка передбачає проходження студентами двох окремих циклів: зокрема, в осінньому семестрі - «Загальні питання організації та проведення судовомедичної експертизи та медичне законодавство», а у весняному семестрі - циклу «Судово-медична травматологія».

Успішно себе зарекомендувала дистанційна система оцінювання знань у програмному середовищі «Moodle», яка забезпечує максимально об'єктивний контроль рівня знань студентів як під час практичного заняття, так і на єдиному комплексному тестовому іспиті. Результати цих тестувань автоматично заносяться в базу даних, на підставі чого формується індивідуальний рейтинг кожного студента.

Широке використання комп'ютерних технологій у навчальному процесі та під час семестрових іспитів неможливе без достатнього банку тестових завдань, який сьогодні налічує близько 10000 ситуаційних задач, тестів 3 малюнками та текстових тестів (українською, англійською та російською мовами) і регулярно поновлюється.

Крім електронного супроводу, створено належне навчально-методичне забезпечення дисципліни: власні навчальні підручники, посібники, навчальні відеофільми та лазерні компакт-диски, методичні розробки, навчальні таблиці. Всі навчально-методичні матеріали представлені на сайті університету, знаходяться у вільному доступі для студентів та викладачів, активно використовуються ними при підготовці до практичних занять і лекцій.

Актуальною при вивченні судової медицини $€$ якісна підготовка самостійної роботи студентів та об'єктивне оцінювання викладачами матеріалу, який не увійшов до плану аудиторних занять та лекцій [2]. У ТДМУ ця робота реалізується студентами шляхом підготовки рефератів або мультимедійних презентацій на відповідні теми. Виконання самостійної роботи у вигляді презентацій доповідей дозволяє майбутнім лікарям продемонструвати творчий підхід, проявити ораторські здібності, сприяє зацікавленості в подальшому вивченні дисципліни, що нерідко виявляє здібних до наукової роботи.

Важливою складовою комплексної підготовки майбутніх лікарів $є$ удосконалення лекційного курсу, що забезпечується досвідченими викла- дачами, які окрім педагогічного, володіють достатнім практичним досвідом із питань судовомедичної експертизи. Всі лекції підготовлені в мультимедійному форматі, супроводжуються відеороликами чи відеофрагментами, що, в сукупності, суттєво покращує засвоєння та сприйняття слухачами матеріалу. За розкладом, в університеті передбачений окремий лекційний день у кожному навчальному тижні, що надає студентам можливість теоретичної підготовки до кожної лекції. Маючи запас знань, студенти можуть зосереджуватися на найбільш важливому матеріалі, виділивши для себе головне, а також у спілкуванні безпосередньо із лектором знайти відповіді на запитання, що виникають.

Успішно зарекомендувала себе методика практичної роботи студентів у судово-медичному музеї кафедри, а також їх участь у проведенні судово-медичних розтинів у випадках різноманітних травм, отруєнь чи наглої смерті або під час огляду потерпілих із приводу встановлення ступеня тяжкості тілесних ушкоджень.

\section{Висновок}

Впровадження у навчальний процес новітніх технологій викладання, у сукупності із застосуванням сучасних електронних засобів комунікації, забезпечує достатній рівень теоретичного опанування дисципліни «Судова медицина, медичне законодавство» та набуття студентами необхідних практичних навичок, що, у кінцевому підсумку, забезпечує засвоєння навчальної програми 3 дисципліни за кращими світовими освітніми стандартами.

Перспективи подальших досліджень. Доцільно визначити ступінь засвоєння студентами теоретичного і практичного матеріалу на основі ретроспективного і перспективного аналізу успішності.

\section{Література}

1. Богатирьова Р.В. Основні завдання вищої медичної освіти у процесі реформування системи охорони здоров'я України / Р.В. Богатирьова // Мед. освіта. 2013. - № 2. - C. 5-8

2. Будко Г.Ю. Оптимізація навчально-педагогічного процесу з вивчення курсу судової медицини у вищих медичних навчальних закладах / Г.Ю. Будко, Л.І. Карпенко // Суд.-мед. експертиза: матеріали Всеукр. конференції [“Актуальні питання суд.-мед. науки, освіти i практики"], 18-19 жовтня 2012p. - 2012. - № 6. C. $122-124$.

3. Ковальчук Л.Я. Новітні шляхи вдосконалення підготовки фахівців у Тернопільському державному медичному університеті імені І.Я. Горбачевського / Л.Я. Ковальчук // Мед. освіта. - 2010. - № 2. - С. 27-30.

4. Оптимізація і шляхи вдосконалення викладання судової медицини та медичного правознавства у ВМ $(\Phi) Н 3$ України як аспект формування кваліфікаційного рівня майбутніх спеціалістів-стоматологів / Г.Ф. Кривда, Р.Г. Кривда, Л.М. Ларсон [та ін.] // Мед. освіта. 2012. - № 3. - С. 90-92.

5. Осійчук М.С. Вплив євроінтеграційних процесів на розвиток вищої медичної освіти / М.С. Осійчук // Мед. освіта. - 2013. - № 2. - С. 9-13. 


\title{
ВНЕДРЕНИЕ ИННОВАЦИОННЫХ ТЕХНОЛОГИЙ ОБУЧЕНИЯ ПРИ ПРЕПОДАВАНИИ ДИСЦИПЛИНЫ “СУДЕБНАЯ МЕДИЦИНА, МЕДИЦИНСКОЕ ЗАКОНОДАТЕЛЬСТВО”
}

\author{
В.В. Франчук, Я.Я. Боднарь, С.В. Трач-Росоловская, А.З. Миколенко
}

Резюме. В статье освещены современные технологии обучения, которые внедрены при преподавании судебной медицины в Тернопольском государственном медицинском университете.

Ключевые слова: преподавание судебной медицины, инновационные технология обучения.

\section{INTRODUCTION OF INNIVATION EDUCATIONAL TECHNOLOGIES, WHILE TEACHING THE SUBJECT "FORENSIC MEDICINE AND MEDICAL LEGISLATION"}

\section{V.V. Franchuk, Ya.Ya. Bodnar, S.V. Trach-Rosolovska, A.Z. Mykolenko}

Abstract. The paper has ascertained modern technolologies of teaching Forensic Medicine at Ternopil State Medical University that are introduced into the process of teaching.

Key words: teaching forensic medicine, innovative technologies.

SHEI “State Medical University Named after I. Ya. Horbachevskyi” (Ternopil')

Рецензент - проф. В.Т. Бачинський

Buk. Med. Herald. - 2013. - Vol. 17, № 3 (67), part 1. - P. 176-178

Надійшла до редакції 06.06.2013 року

(C) В.В. Франчук, Я.Я. Боднар, С.В. Трач-Росоловська, А.З. Миколенко, 2013

УДК 340.6:616-091

\section{В.В. Хижняк, Л.А. Старагина}

\section{ВЛИЯНИЕ ПРИЧИНЫ СМЕРТИ НА ПОЛИХРОМИЮ ТРУПНЫХ ПЯТЕН}

Харьковский национальный медицинский университет

Резюме. Констатируем постоянный интерес судебных медиков к изучению трупных пятен. Предлагаем оригинальный способ унификации регистрации по-

Введение. Длительное время трупные пятна являются постоянным объектом исследования многих поколений судебных медиков. По интенсивности трупных пятен, скорости их появления и развития, по цвету трупных пятен на месте обнаружения трупа можно определить время наступления смерти и предугадать причину смерти. Ранее уже делались попытки объективного определения цветов [1], но без акцента на трупные пятна.

Цель исследования. Изучить полихромию трупных пятен в зависимости от причины смерти.

Материал и методы. Разработаны регистрационные карточки на каждый обследуемый труп, которые включали в себя паспортную часть и обстоятельства случая. Использовались данные из медицинской документации умерших, а также данные из врачебных свидетельств о смерти.

Как сообщалось ранее, для [2] изучения взаимосвязи изменения цвета трупных пятен в зависимости от причины смерти исследовано 100 случаев смерти. Материал группировался по причинам смерти: 1. Постинфарктный кардиосклероз; 2. Травматический шок; 3. Механическая лихромии трупных пятен. Выявили зависимость цвета трупных пятен от причины смерти.

Ключевые слова: причина смерти, трупные пятна, полихромия.

асфиксия; 4. Рак; 5. Инсульт; 6. Инфаркт; 7. Кардиомиопатия; 8. Отравление; 9. Кровопотеря; 10. Заболевания легких; 11. Хронические сердечно-сосудистые заболевания. Изучение цвета трупных пятен проводилось с помощью цветовой палитры RAL E3 EFFECT, которая является международным стандартом. Исследование проводилось в ходе осмотра трупов на местах происшествия.

Результаты исследования и их обсуждение. Для причины смерти такой, как постинфарктный кардиосклероз, кардиомиопатия, инфаркт миокарда, характерный цвет трупных пятен - 560-3. При сочетании этих патологических состояний с коронарокардиосклерозом, сердечно-сосудистой недостаточностью, хронической ишемической болезнью сердца, атеросклеротической болезнью сердца трупные пятна имеют характерные цвета 540-3 (9 случаев), 550-4 (9 случаев), 550-6 (8 случаев), 560-4 (8 случаев) соответственно. При механической асфиксии характерный цвет - 550-3 (5 случаев), а если асфиксия на фоне опухолевых заболеваний, то характерный цвет трупных пя-

(C) В.В. Хижняк, Л.А. Старагина, 2013 